\title{
Case report: dual primary AIDS-defining cancers in an HIV-infected patient receiving antiretroviral therapy: Burkitt's lymphoma and Kaposi's sarcoma
}

Seong Eun Kim ${ }^{1}$, Younggon Jung ${ }^{1} \mathbb{D}$, Tae Hoon Oh${ }^{1}$, Uh Jin Kim', Seung-Ji Kang ${ }^{1}$, Hee-Chang Jang ${ }^{1}$, Kyung-Hwa Park', Kyung-Hwa Lee ${ }^{2}$ and Sook In Jung ${ }^{1 *}$

\begin{abstract}
Background: The incidence of AIDS-defining cancers (ADCs) has decreased markedly in the era of highly active antiretroviral therapy (HAART). The occurrence of two ADCs is rare in people living with HIV or AIDS (PWHA) who are severely immunosuppressed or have incomplete virologic suppression.

Case presentation: We report a case of dual primary ADCs, especially NHL followed by KS, in a 70-year-old HIVinfected man who was on antiretroviral therapy and had successful virologic suppression. During HAART, he presented with generalized myalgia and abdominal pain. Multiple liver masses were detected and a biopsy revealed Burkitt's lymphoma. After three cycles of anticancer chemotherapy with a favorable response, he was diagnosed with cytomegalovirus retinitis and the anti-cancer chemotherapy was discontinued. Despite successful virologic suppression with HAART, human herpes virus-8 associated Kaposi's sarcoma was diagnosed in his right thigh. He underwent radiation therapy.

Conclusion: These findings suggest that multiple ADCs can occur in PWHA who are receiving HAART and have successful virologic suppression. Healthcare providers caring for PWHA should maintain vigilance for the development of a broad spectrum of cancers.
\end{abstract}

Keywords: HIV, Burkitt's lymphoma, Kaposi's sarcoma, Antiretroviral therapy

\section{Background}

The introduction of highly active antiretroviral therapy (HAART) has changed the natural history of opportunistic infections (OIs) and malignancies among people with HIV or AIDS (PWHA). The incidence of AIDS-defining cancers (ADCs), including Kaposi's sarcoma (KS), non-Hodgkin lymphoma (NHL), and invasive cervical cancer, has decreased significantly [1-3]. Conversely, an increased incidence of non-AIDS related cancers (NADCs) has been reported, especially cancers of the lungs, liver, kidneys, anus, head and neck, and skin, as well as Hodgkin lymphoma [4-7]. ADCs are associated with

\footnotetext{
* Correspondence: sijung@chonnam.ac.kr

${ }^{1}$ Department of Infectious Diseases, Chonnam National University Medical

School, 42, Jebong Ro, Donggu, Gwangju 61469, Korea

Full list of author information is available at the end of the article
}

oncogenic viral infections, including Epstein-Barr virus (EBV), human herpes virus type 8 (HHV-8), cytomegalovirus (CMV), papillomavirus, and possibly other viral agents $[3,8]$. The restoration of immune function by HAART may contribute to the decreased incidence of ADCs, which results in fewer AIDS-related deaths.

The occurrence of dual ADCs is rare in the era of antiretroviral therapy. Here, we describe a case of dual primary ADCs in an HIV-infected patient who was receiving HAART and had successful viral suppression.

\section{Case presentation}

A 70-year-old bisexual man was admitted with generalized myalgia and abdominal pain lasting for 7 days. Three months earlier, he was diagnosed with HIV infection during the evaluation of a fever. The initial HIV 
RNA level was 36,500 copies $/ \mathrm{mL}$, with $114 \mathrm{CD}^{+}$lymphocytes $/ \mu \mathrm{L}$, which were consistent with the definition of AIDS [9] although the exact timing of HIV infection was unknown. At that time, abdominal and chest computed tomography (CT) showed no abnormality and an ophthalmologic examination showed no evidence of ocular disease. In addition, anti-cytomegalovirus (CMV) IgG was positive. For 3 months, he was treated with an integrase strand transfer inhibitor (INSTI)-based regimen (elvitegravir, cobicistat, tenofovir disoproxil fumarate, and emtricitabine) and showed good adherence.

At the time of the current admission, his vital signs were: blood pressure, $110 / 80 \mathrm{mmHg}$; pulse rate, $98 / \mathrm{min}$; body temperature, $38.0{ }^{\circ} \mathrm{C}$; and respiratory rate, $20 / \mathrm{min}$. There was no localized tenderness of the abdomen on physical examination. The laboratory findings showed anemia (hemoglobin, $9.7 \mathrm{~g} / \mathrm{dL}$ ), thrombocytopenia (platelets, $53 \times 10^{3} / \mathrm{mm}^{3}$ ), acute kidney injury (creatinine, $1.8 \mathrm{mg} / \mathrm{dL}$ ), and an elevated lactate dehydrogenase level (LDH; 6608 U/L). No HIV-RNA was detected (<20 copies $/ \mathrm{mL}$ ), and there were $256 \mathrm{CD}^{+}$lymphocytes $/ \mu \mathrm{L}$. Abdominal CT revealed multiple liver masses (Fig. 1a), and a core needle biopsy was performed to differentiate between liver abscess and malignancy. An atypical lymphocytic population composed of medium-sized basophilic cells was observed on hematoxylin and eosin staining (Fig. 2a). Immunohistochemistry was positive for the B cell markers CD20 (Fig. 2b) and CD79a (Fig. 2c), and the Ki-67 labelling index approached $90 \%$. The tumor cells were also positive on EBV in situ hybridization (Fig. 2d). The liver lesion was diagnosed as Burkitt's lymphoma. An additional diffuse hypermetabolic bone marrow lesion was found on positron emission tomography-CT (PET/CT), and he was confirmed to have stage IV Burkitt's lymphoma by the Lugano classification.

Three cycles of antineoplastic chemotherapy based on rituximab plus fractionated cyclophosphamide, vincristine, doxorubicin, and dexamethasone (R-hyper-CVAD) were administered, and two cycles of methotrexate were given via an intrathecal route. The HAART was replaced with another INSTI-based regimen (raltegravir, tenofovir disoproxil fumarate, and emtricitabine) after considering potential drug interactions. Interim PET/ CT showed a partial response with marked improvement of the lymphomatous involvement in the bone marrow and liver, but hypermetabolic para-aortic, aortocaval lymph nodes remained 3 months after initiating chemotherapy.

Just after the third cycle of R-hyper-CVAD, the patient suddenly complained of decreased visual acuity and an ophthalmologist diagnosed CMV retinitis. At that time, there were $56 \mathrm{CD}^{+}$lymphocytes $/ \mu \mathrm{L}$, but no HIV RNA was detected $(<20$ copies $/ \mathrm{mL})$. Intravitreal and intravenous ganciclovir were used for induction therapy, and valganciclovir maintenance therapy was continued. Chemotherapy was stopped after the third cycle of R-hyper-CVAD due to intolerance and the CMV retinitis. Four months after discontinuing the chemotherapy, $\mathrm{PET} / \mathrm{CT}$ showed disease progression in the para-aortic, aortocaval lymph nodes, and newly developed lymphomatous involvement was seen in the paravertebral and cardiophrenic space.

Ten months after discontinuing systemic chemotherapy, the patient developed swelling and pain in his right thigh. CT showed edematous changes and skin thickening in this area (Fig. 1b, arrow), but there was no remarkable size increase in the inguinal lymph nodes. There were $129 \mathrm{CD}^{+}$lymphocytes/ $\mu \mathrm{L}$, and HIV RNA was undetectable. A skin punch biopsy was performed because it was unclear whether the manifestation was related to the Burkitt's lymphoma. The biopsy specimen was composed predominantly of plump spindle cells with intervening vascular spaces (Fig. 3a). Despite the bland cytology of the tumor cells, frequent mitotic figures were seen and the tumor was infiltrating the dermal collagen fibers. The tumor cells were positive for CD31 (Fig. 3b) and HHV-8 latent nuclear antigen-1 (LNA-1) by immunohistochemistry (Fig. 3c). The histology was

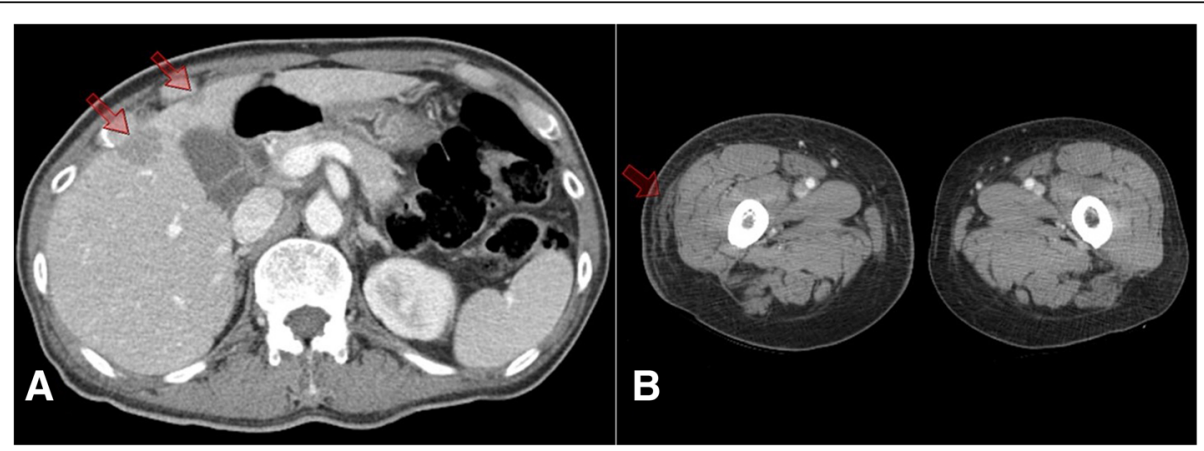

Fig. 1 (a) CT of the abdomen revealed 2.5- and 1.5-cm low-attenuated lesions in liver segment 5, with other smaller lesions in both hepatic lobes. (b) Thigh CT showed edematous changes in subcutaneous tissues of the right thigh 


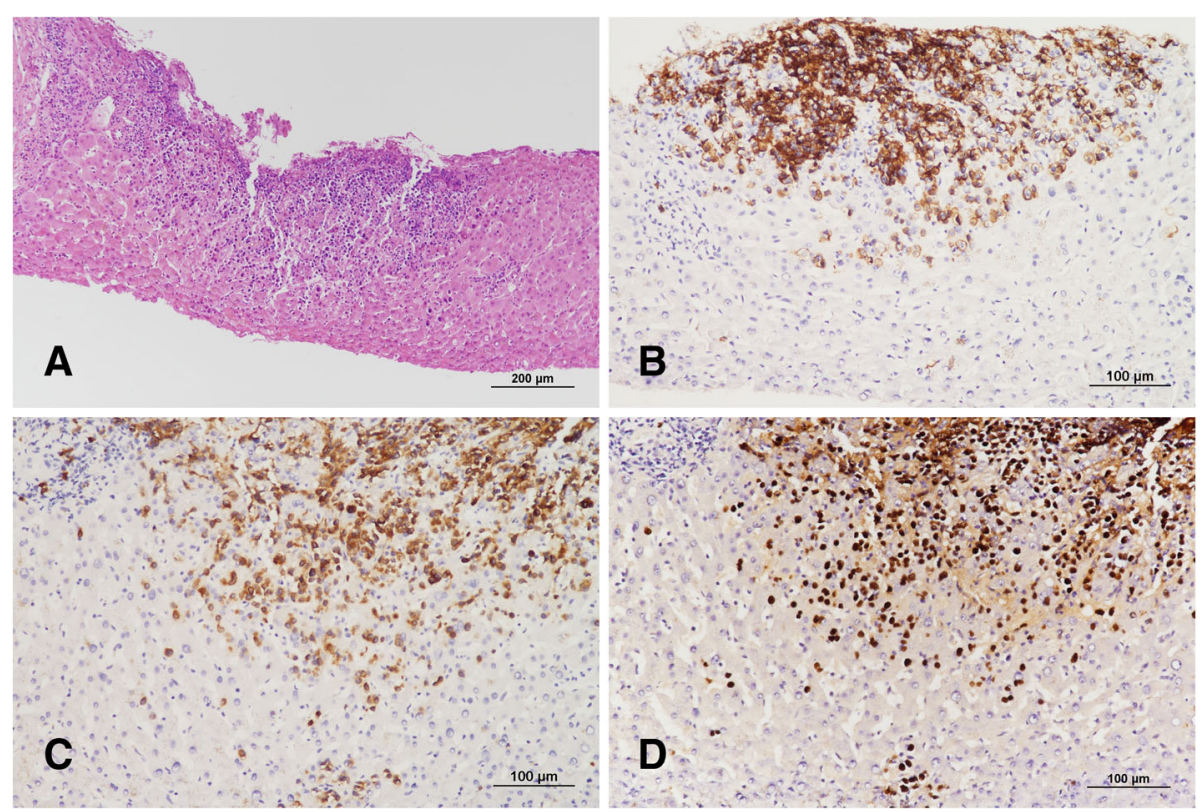

Fig. 2 (a) Histopathologically, the core biopsy from the liver showed a dense lymphocytic infiltration in the parenchyma (hematoxylin and eosin staining, original magnification $\times 100)$. (b-c) The tumor cells were immunopositive for CD20 (b) and CD79a (c) (immunohistochemistry, original magnification $\times 200$ ). (d) The tumor cells displayed strong positivity on EBV in situ hybridization, consistent with Burkitt's lymphoma (in situ hybridization, original magnification $\times 200$ )

consistent with KS. Twenty Grays of radiation were given in five fractions without systemic chemotherapy. Two months after radiation therapy, multiorgan (bone, liver, and pericardium) lymphoma aggravation led to his death.

\section{Discussion}

To our knowledge, this is the first described case of dual primary ADCs (NHL, followed by KS) in an HIV-infected patient who was receiving HAART and had successful viral suppression. Before the era of
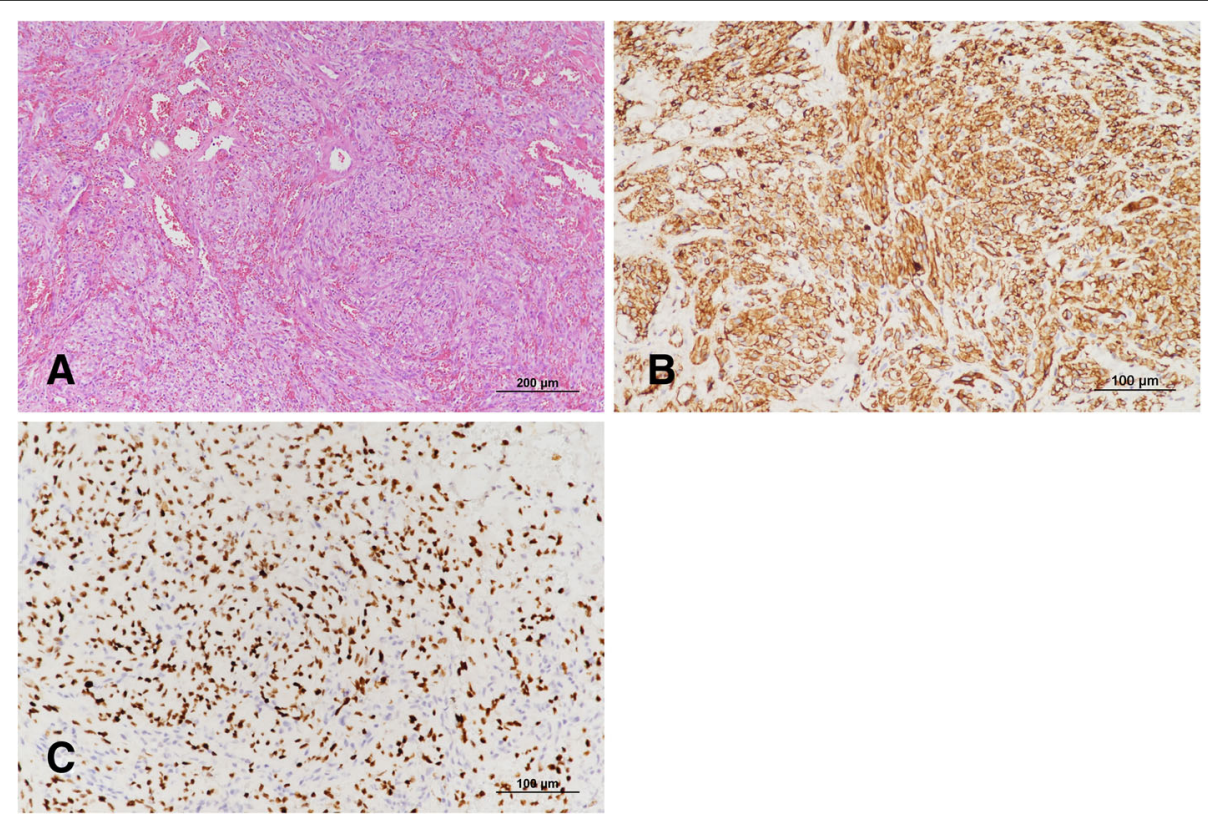

Fig. 3 (a) The skin biopsy revealed a highly cellular lesion composed of bland spindle cells and intervening irregular vascular spaces (hematoxylin and eosin staining, original magnification $\times 100$ ). $(\mathbf{b}-\mathbf{c})$ The tumor cells were strongly positive for CD31 (b) and HHV-8 LNA-1 (c), a diagnostic marker of KS (immunohistochemistry, original magnification $\times 200$ ) 
HAART, opportunistic infections and malignancies were major causes of death in PWHA. The introduction of HAART changed the trend in malignancies in PWHA in many countries [10-12]. The decrease in the prevalence of severe immunodeficiency resulted in a rapid reduction of new ADCs, such as KS and NHL $[8,11,13,14]$. The Swiss HIV cohort study reported that the incidence of KS and NHL declined from $1,375 / 10^{5}$ and $952 / 10^{5}$ in the pre-HAART era (1985-1996) to $66.9 / 10^{5}$ and $98.4 /$ $10^{5}$, respectively, in the late HAART (2002-2006) period [13]. The incidence of ADCs is higher when patients have lower CD4 cell counts, initially present with cancer or revisit after loss to follow-up [15]. Conversely, the risk of $\mathrm{ADC}$ is reduced markedly among patients who remain in care and continue HAART [5]. Coexisting or metachronous KS and NHL are rarely reported in PWHA who have severe immunosuppression or incomplete virologic suppression [16-18]. Furthermore, KS developed first, followed by NHL, or these two ADCs developed simultaneously. Interestingly, the reduction in incidence after the introduction of HAART was pronounced for KS compared with NHL [8]. This suggests that patients cease to be at risk of KS once HAART has improved immune function, although patients with a history of severe immunodeficiency continue to be at risk of NHL despite HAART. In this report, NHL was detected first in a patient who was receiving HAART and showed successful viral suppression; KS developed 13 months later, despite discontinuing systemic chemotherapy for NHL. Dual primary malignancies are not uncommon in the general population. However, the relative risk of multiple ADCs in patients with HIV-related immunodeficiency is unknown. Our findings indicate the possibility of multiple ADCs in PWHA who are receiving HAART and show successful virologic suppression.

HIV-related Burkitt's lymphoma constitutes $24-35 \%$ of all HIV-related NHLs [19]. The cure rate was unsatisfactory in patients with HIV-related NHL before HAART, whereas the introduction of HAART increased the treatment options and improved the outcomes for patients with HIV-related Burkitt's lymphoma [20]. HAART reduces the decline in CD4 counts during chemotherapy, ameliorating the potential for opportunistic infections. Our patient received HAART continuously during cytotoxic chemotherapy. However, in this patient, chemotherapy for Burkitt's lymphoma could not be continued because of the occurrence of CMV retinitis despite an excellent response to chemotherapy. CMV reactivation during conventional chemotherapy may occur in a high proportion of patient, resulting in CMV-associated diseases [21]. A number of challenges exist in the management of Burkitt's lymphoma in PWHA. Along with the high risk of tumor lysis syndrome caused by the high tumor burden, physicians should pay attention to the development of infectious or non-infectious complications during cytotoxic chemotherapy.

HHV-8 infection is necessary for the development of KS [22]. KS was the most common ADC in PWHA, especially homosexual men in the early 1980s [23]. After the introduction of HAART, KS decreased dramatically in both the US and Europe [24]. There are three possible mechanisms by which HAART could block KS. They are HAART-induced immune reconstitution against HHV-8 and infected cells $[25,26]$, reduced circulating levels of HIV-1 Tat protein and inflammatory cytokines [27-29], and direct anti-spindle cell or anti-angiogenic effects of protease inhibitors [30]. In our patient, KS occurred while he was receiving HAART. KS has recently been reported to occur in people with a well-controlled HIV infection and $\mathrm{CD}_{4}^{+}$T-cell count $>200$ cells $/ \mathrm{mm}^{3}$. A recent study revealed that imperfect HAART adherence and a latest $\mathrm{CD} 4$ count $<350$ cells $/ \mu \mathrm{L}$ were significantly associated with KS development [31]. CD4 lymphocytes are recovered and resulting plateau about $2-3$ years after HAART [32]. More frequent incomplete response (< $500 / \mu \mathrm{L}$ ) was seen in patients with low CD4 T lymphocyte counts at baseline or long duration of pre-treatment HIV infection [33]. In this patient, initial $\mathrm{CD}^{+}$lymphocyte count at diagnosis was 114 cells $/ \mu \mathrm{L}$. At the time of KS diagnosis, our patient's $\mathrm{CD} 4^{+}$lymphocyte count was 129 cells/ $\mu \mathrm{L}$ although no HIV RNA was detected. The risk for subsequent KS among NHL survivors is relatively high in the general population [34]. Although the risk for the development of KS in HIV-positive NHL survivors is not known, the damaged immune system caused by HIV infection, NHL progression, and cytotoxic chemotherapy might have contributed to the development of KS in this patient.

Tests determining the risk of opportunistic infections should be performed for every patient with HIV entering into care as recommended in HIV primary care and opportunitstic infection guidelines [35, 36]. CMV retinitis can be diagnosed through a dilated pupil during an ophthalmoscopic examination by an experienced ophthalmologist. However, blood tests including CMV antigen detection, culture, or PCR are not recommended for diagnosis of CMV end-organ disease because of their poor positive predictive values. Serum antibody to CMV is not diagnostically useful [36]. In addition, use of serologic testing for HHV-8 antibodies is currently not indicated for either diagnostic testing or routine screening for HHV-8-related illnesses due to lack of standardization and poor sensitivity and specificity [37]. Although HIV-infected patients are more likely to have detectable plasma EBV DNA than are HIV-uninfected control subjects, the absolute level of EBV DNA is not predictive of progression to AIDS-related NHL [38]. In this patient, serum IgG antibody to CMV was detected at the time of 
HIV diagnosis. However, ophthalmologic examination revealed no evidence of CMV retinitis. Chest and abdominal CT showed no abnormality initially. Eventually, dual primary ADCs and CMV retinitis occurred despite viral suppression. Clinicians continue to monitor ADCs and OIs even in the situation of successful viral suppression with ART. Furthermore, development of diagnostic tools to easily predict ADCs and OIs is needed.

\section{Conclusion}

In summary, dual primary ADCs, especially NHL followed by KS, are uncommon in PWHA who are receiving HAART and show successful virologic suppression. Healthcare providers caring for PWHA should maintain high vigilance for the development of a broad spectrum of cancers in all HIV/AIDS patients.

\section{Abbreviations}

ADCs: AIDS defining cancers; CD: Cluster of differentiation;

CMV: Cytomegalovirus; CT: Computed tomography; EBV: Epstein-Barr virus; HAART: Highly active antiretroviral therapy; HHV-8: Human herpes virus type 8; INSTI: Integrase strand transfer inhibitor; KS: Kaposi's sarcoma; LDH: Lactate dehydrogenase; LNA-1: Latent nuclear antigen-1; NADC: Non-AIDS related cancers; NHL: Non-Hodgkin's lymphoma; Ol: Opportunistic infection; PETCT: Positron emission tomography-computed tomography; PWHA: People with HIV or AIDS; R-hyper-CVAD: Rituximab plus fractionated cyclophosphamide, vincristine, doxorubicin, and dexamethasone

\section{Acknowledgements}

None.

\section{Funding}

No funding was required for the writing of this case report.

\section{Availability of data and materials}

Not applicable (no datasets were generated or analyzed during the current study)

\section{Authors' contributions}

SEK, SJK, HCJ, SIJ - participated in the clinical care of the patient on the ward. YJ, THO, UJK, HCJ- advised and supervised the laboratory testing, interpretation and reporting. YJ, KHL - perform pathologic diagnosis and report. THO, SJK, UJK, KHP, SIJ - were responsible for the concept for and critical contribution and revision to this manuscript. SEK, KHL, SIJ - wrote the manuscript. All authors critically reviewed the manuscript for publication. All authors read and approved the final manuscript."

\section{Ethics approval and consent to participate}

Not applicable.

\section{Consent for publication}

Written consent to publish this case report was obtained from the patient (Consent No. 2017-JN24).

\section{Competing interests}

The authors declare that they have no competing interests.

\section{Publisher's Note}

Springer Nature remains neutral with regard to jurisdictional claims in published maps and institutional affiliations.

\section{Author details}

'Department of Infectious Diseases, Chonnam National University Medical School, 42, Jebong Ro, Donggu, Gwangju 61469, Korea. ${ }^{2}$ Department of Pathology, Chonnam National University Medical School, Gwangju, Republic of Korea.
Received: 7 August 2018 Accepted: 31 October 2018

Published online: 08 November 2018

\section{References}

1. Shiels MS, Engels EA. Evolving epidemiology of HIV-associated malignancies, Curr Opin HIV AIDS. 2017;12:6-11.

2. Centers for Disease Control and Prevention. HIV surveillance - United States, 1981-2008. MMWR Morb Mortal Wkly Rep. 2011;60:689-93.

3. Mortality GBD, Causes of Death C. Global, regional, and national life expectancy, all-cause mortality, and cause-specific mortality for 249 causes of death, 1980-2015: a systematic analysis for the global burden of disease study 2015. Lancet. 2016;388:1459-544.

4. Grulich AE. Cancer: the effects of HIV and antiretroviral therapy, and implications for early antiretroviral therapy initiation. Curr Opin HIV AIDS. 2009;4:183-7.

5. Lee S, Lee SH, Lee JE, Kang JS, Lee SG, Chung JS, Kwak IS. Trends in malignancies among Korean patients infected with human immunodeficiency virus in the highly active antiretroviral therapy era. J Korean Med Sci. 2017;32:1445-50.

6. Grulich $A E$, van Leeuwen MT, Falster MO, Vajdic CM. Incidence of cancers in people with HIV/AIDS compared with immunosuppressed transplant recipients: a meta-analysis. Lancet. 2007;370:59-67.

7. Deeken JF, Tjen ALA, Rudek MA, Okuliar C, Young M, Little RF, Dezube BJ. The rising challenge of non-AIDS-defining cancers in HIV-infected patients. Clin Infect Dis. 2012;55:1228-35.

8. Ledergerber B, Telenti A, Egger M. Risk of HIV related Kaposi's sarcoma and non-Hodgkin's lymphoma with potent antiretroviral therapy: prospective cohort study. Swiss HIV cohort study. BMJ. 1999;319:23-4.

9. Centers for Disease Control and Prevention. Revised classification system for HIV infection and expanded case definitions for AIDS among adolescents and adults. MMWR. 1993;41 (RR-17):1992.

10. Chen M, Jen I, Chen YH, Lin MW, Bhatia K, Sharp GB, Law MG, Arthur Chen YM. Cancer incidence in a Nationwide HIV/AIDS patient cohort in Taiwan in 1998-2009. J Acquir Immune Defic Syndr. 2014;65:463-72.

11. Polesel J, Franceschi S, Suligoi B, Crocetti E, Falcini F, Guzzinati S, Vercelli M, Zanetti R, Tagliabue G, Russo A, Luminari S, Stracci F, De Lisi V, Ferretti S, Mangone L, Budroni M, Limina RM, Piffer S, Serraino D, Bellù F, Giacomin A, Donato A, Madeddu A, Vitarelli S, Fusco M, Tessandori R, Tumino R, Piselli P, Dal Maso L; Cancer and AIDS Registries Linkage Study Cancer; AIDS Registries Linkage Study, Lise M, Zucchetto A, De Paoli A, Intrieri T, Vattiato R, Zambon P, Puppo A, Patriarca S, Tittarelli A, Autelitano M, Cirilli C, La Rosa F, Sgargi P, Di Felice E, Cesaraccio R, Donato F, Franchini S, Zanier L, Vittadello F, Vercellino PC, Senatore G, Contrino ML, Antonini S, Palombino R, Maspero S, La Rosa MG, Camoni L, Regine V. Cancer incidence in people with AIDS in Italy. Int J Cancer 2010:127:1437-1445.

12. Robbins HA, Shiels MS, Pfeiffer RM, Engels EA. Epidemiologic contributions to recent cancer trends among HIV-infected people in the United States. AIDS. 2014;28:881-90.

13. Franceschi S, Lise M, Clifford GM, Rickenbach M, Levi F, Maspoli M, Bouchardy C, Dehler S, Jundt G, Ess S, Bordoni A, Konzelmann I, Frick H, Dal Maso L, Elzi L, Furrer H, Calmy A, Cavassini M, Ledergerber B, Keiser O, Swiss HIV cohort study. Changing patterns of cancer incidence in the early- and late-HAART periods: the Swiss HIV cohort study. Br I Cancer. 2010;103:416-22

14. Antiretroviral Therapy Cohort Collaboration (ART-CC), Mocroft A, Sterne JA, Egger M, May M, Grabar S, Furrer H, Sabin C, Fatkenheuer G, Justice A, Reiss P, d'Arminio Monforte A, Gill J, Hogg R, Bonnet F, Kitahata M, Staszewski S, Casabona J, Harris R, Saag M. Variable impact on mortality of AIDS-defining events diagnosed during combination antiretroviral therapy: not all AIDSdefining conditions are created equal. Clin Infect Dis. 2009;48:1138-51.

15. Dubrow R, Silverberg MJ, Park LS, Crothers K, Justice AC. HIV infection, aging, and immune function: implications for cancer risk and prevention. Curr Opin Oncol. 2012;24:506-16.

16. Wang B, Song B, Oster C, Cao J, Raza A, Wang J. Coexistence of intestinal Kaposi sarcoma and plasmablastic lymphoma in an HIV/AIDS patient: case report and review of the literature. J Gastrointest Oncol. 2016;7:S88-95.

17. Manfredi R, Calza L, Chiodo F. Multiple AIDS-related malignancies just in the era of potent antiretroviral therapy. A rare but intriguing finding. Infez Med. 2003;1 1:153-6.

18. Ascoli V, Mastroianni CM, Galati V, Sirianni MC, Fruscalzo A, Pistilli A, Lo Coco F. Primary effusion lymphoma containing human herpesvirus 8 DNA in two AIDS patients with Kaposi's sarcoma. Haematologica. 1998;83:8-12.

19. Hecht JL, Aster JC. Molecular biology of Burkitt's lymphoma. J Clin Oncol. 2000;18:3707-21. 
20. Levine AM. Challenges in the management of Burkitt's lymphoma. Clin Lymphoma. 2002;3(Suppl 1):S19-25.

21. Kuo CP, Wu CL, Ho HT, Chen CG, Liu SI, Lu YT. Detection of cytomegalovirus reactivation in cancer patients receiving chemotherapy. Clin Microbiol Infect. 2008;14:221-7.

22. Chang Y, Cesarman E, Pessin MS, Lee F, Culpepper J, Knowles DM, Moore PS. Identification of herpesvirus-like DNA sequences in AIDS-associated Kaposi's sarcoma. Science. 1994;266:1865-9.

23. Katz MH, Hessol NA, Buchbinder SP, Hirozawa A, O'Malley P, Holmberg SD. Temporal trends of opportunistic infections and malignancies in homosexual men with AIDS. J Infect Dis. 1994;170:198-202.

24. La Ferla L, Pinzone MR, Nunnari G, Martellotta F, Lleshi A, Tirelli U, De Paoli P, Berretta M, Cacopardo B. Kaposi' s sarcoma in HIV-positive patients: the state of art in the HAART-era. Eur Rev Med Pharmacol Sci. 2013;17:2354-65.

25. Brander C, Suscovich T, Lee Y, Nguyen PT, O'Connor P, Seebach J, Jones NG, van Gorder M, Walker BD, Scadden DT. Impaired CTL recognition of cells latently infected with Kaposi's sarcoma-associated herpes virus. J Immunol. 2000;165:2077-83.

26. Wilkinson J, Cope A, Gill J, Bourboulia D, Hayes P, Imami N, Kubo T, Marcelin A, Calvez V, Weiss R, Gazzard B, Boshoff C, Gotch F. Identification of Kaposi's sarcoma-associated herpesvirus (KSHV)-specific cytotoxic T-lymphocyte epitopes and evaluation of reconstitution of KSHV-specific responses in human immunodeficiency virus type 1-infected patients receiving highly active antiretroviral therapy. J Virol. 2002;76:2634-40.

27. Ensoli B, Barillari G, Salahuddin SZ, Gallo RC, Wong-Staal F. Tat protein of HIV-1 stimulates growth of cells derived from Kaposi's sarcoma lesions of AIDS patients. Nature. 1990;345:84-6.

28. Ensoli B, Gendelman R, Markham P, Fiorelli V, Colombini S, Raffeld M, Cafaro A, Chang HK, Brady JN, Gallo RC. Synergy between basic fibroblast growth factor and HIV-1 tat protein in induction of Kaposi's sarcoma. Nature. 1994;371:674-80.

29. Tovo PA. Highly active antiretroviral therapy inhibits cytokine production in HIV-uninfected subjects. AIDS. 2000;14:743-4.

30. Sgadari C, Barillari G, Toschi E, Carlei D, Bacigalupo I, Baccarini S, Palladino C, Leone P, Bugarini R, Malavasi L, Cafaro A, Falchi M, Valdembri D, Rezza G, Bussolino F, Monini P, Ensoli B. HIV protease inhibitors are potent anti-angiogenic molecules and promote regression of Kaposi sarcoma. Nat Med. 2002;8:225-32.

31. Lupia R, Wabuyia PB, Otiato P, Fang CT, Tsai FJ. Risk factors for Kaposi's sarcoma in human immunodeficiency virus patients after initiation of antiretroviral therapy: a nested case-control study in Kenya. J Microbiol Immunol Infect. 2017;50:781-8.

32. Kaufmann GR, Perrin L, Pantaleo G, Opravil M, Furrer H, Telenti A, Hirschel B, Ledergerber B, Vernazza P, Bernasconi E, Rickenbach M, Egger M, Battegay M, Swiss HIV Cohort Study Group. CD4 T-lymphocyte recovery in individuals with advanced HIV-1 infection receiving potent antiretroviral therapy for 4 years: the Swiss HIV cohort study. Arch Intern Med. 2003;163:2187-95.

33. Kaufmann GR, Furrer $H$, Ledergerber B, Perrin L, Opravil M, Vernazza $P$, Cavassini M, Bernasconi E, Rickenbach M, Hirschel B, Battegay M, Swiss HIV Cohort Study. Characteristics, determinants, and clinical relevance of CD4 T cell recovery to $<500$ cells/microL in HIV type 1-infected individuals receiving potent antiretroviral therapy. Clin Infect Dis. 2005;41:361-72.

34. Dores GM, Cote TR, Travis LB. New malignancies following Hodgkin lymphoma, non-Hodgkin lymphoma, and myeloma. In: Curtis R, Freedman D, Ron E, et al., editors. New Malignancies Among Cancer Survivors: SEER Cancer Registries, 1973-2000. NIH Publ No 05-5302, 2006: p. 397-436. Available at https://seer.cancer.gov/archive/publications/mpmono/ MPMonograph_complete.pdf.

35. Aberg JA, Gallant JE, Ghanem KG, Emmanuel P, Zingman BS, Horberg MA, Infectious Diseases Society of America. Primary care guidelines for the management of persons infected with HIV: 2013 update by the HIV Medicine Association of the Infectious Diseases Society of America. Clin Infect Dis. 2014;58:1-10.

36. Panel on Opportunistic Infections in HIV-Infected Adults and Adolescents. Guidelines for the Prevention and Treatment of Opportunistic Infections in HIVInfected Adults and Adolescents. 2017. Available at https:/aidsinfo.nih.gov/ guidelines/html/4/adult-and-adolescent-oi-prevention-and-treatment-guidelines/0

37. Morrison BJ, Labo N, Miley WJ, Whitby D. Serodiagnosis for tumor viruses. Semin Oncol. 2015;42:191-206.

38. Van Baarle D, Wolthers KC, Hovenkamp E, Hovenkamp E, Niesters HG Osterhaus AD, Miedema F, Van Oers MH. Absolute level of Epstein-Barr virus DNA in human immunodeficiency virus type 1 infection is not predictive of AIDS-related non-Hodgkin lymphoma. J Infect Dis. 2002;186:405-9.

Ready to submit your research? Choose BMC and benefit from:

- fast, convenient online submission

- thorough peer review by experienced researchers in your field

- rapid publication on acceptance

- support for research data, including large and complex data types

- gold Open Access which fosters wider collaboration and increased citations

- maximum visibility for your research: over $100 \mathrm{M}$ website views per year

At BMC, research is always in progress.

Learn more biomedcentral.com/submissions 